\title{
Antagonistic antimicrobial activity of marine fungi and bacteria isolated from marine biofilm and seawaters of Hong Kong
}

\author{
Li Miao, Pei-Yuan Qian* \\ Coastal Marine Laboratory/Department of Biology, Hong Kong University of Science and Technology, Clear Water Bay, \\ Kowloon, Hong Kong, SAR China
}

\begin{abstract}
The antagonistic interaction between marine fungi and marine bacteria was investigated using 19 bacterial species isolated from marine biofilm and 46 waterborne fungal isolates obtained from Hong Kong waters. Of the 46 fungal isolates, $70 \%$ inhibited the growth of at least 1 target bacterial species. Active fungal strains belonged mainly to the genera Cladosporium, Paraphaeosphaeria, Trichoderma, Alternaria, Phoma, and Arthrinium. Eight fungal isolates (17\% of all fungal isolates tested) were sensitive to at least 1 target bacterial species. Eleven of the 19 bacterial species showed antifungal activity. Two Staphylococcus strains inhibited the growth of all of the sensitive fungal strains. The results indicated that marine fungi could provide an important source of natural antimicrofouling compounds and that the interaction between marine fungi and marine bacteria in biofilms cannot easily be generalized.
\end{abstract}

KEY WORDS: Marine fungi $\cdot$ Marine bacteria $\cdot$ Microbial interaction $\cdot$ Microfouling

Resale or republication not permitted without written consent of the publisher

\section{INTRODUCTION}

All surfaces, both animate and inanimate, submerged in seawater become covered with a thin layer of biofilm made of biomolecules, bacteria, fungi, protozoa and diatoms (Clare et al. 1992). This layer is highly complex, dynamic and super rich in molecular signals produced by marine bacteria and diatoms, which can directly control larval settlement and the subsequent growth of marine invertebrates (Harder et al. 2002, Lam et al. 2003, Qian et al. 2003). Since the bacteria in biofilm are important sources of molecular signals, they play a regulatory role in the recruitment patterns and population dynamics of marine organisms.

It has been illustrated that many physical and chemical factors, such as hydrodynamic conditions, the intercellular signal, and metabolic interactions among different cells and species of bacteria, can affect the development of biofilms; thus, the molecular signals for larval settlement produced by a biofilm can change substantially (Wieczorek et al. 1996, Davey \& O'Toole
2000). Interaction among different film components such as marine fungi and bacteria will also undoubtedly have direct effects on the chemical signals produced by the film. Since marine fungi have been identified as major corrosive organisms of man-made marine installations and as pathogens of many marine plants and animals (Kohlmeyer \& Kohlmeyer 1979), much research has focused on the growth of corrosive marine fungi (Bettucci et al. 1999) and the interaction between fungal pathogens and their hosts (Dube et al. 2002). However, the interaction between marine fungi and bacteria in biofilms as well as the role of marine fungi in the development of marine biofilm have hardly been studied, although marine-derived fungi have been shown to produce interesting bioactive metabolites (Bernan et al. 1997, Pietra 1997), including some potential antibiotics (Strongman et al. 1987, Cheng et al. 1994). In comparison, substantial amounts of work have been done on the interaction between terrestrial fungi and bacteria, and this has led to numerous discoveries, including the discovery and 
application of penicillin. Therefore, studying the crosskingdom interaction between marine fungi and bacteria could be of interest for both the applied and pure sciences.

In contrast, since marine biofouling is extremely widespread and causes serious operational problems and huge economic loss (Evans \& Clarkson 1993), many potential antifouling compounds have been isolated from sponges (Martin \& Uriz 1993, Kelman et al. 2001, Kubanek et al. 2002), corals (Michalek \& Bowden 1997, Kelman et al. 1998), algae (Mtolera \& Semesi 1996), ascidians (Wahl et al. 1994), seagrasses (Jensen et al. 1998), sea stars (Iken et al. 2000), and sea pansies (Rittschof et al. 1986). Microorganisms associated with some of these macroorganisms, however, have been suggested as the true source of their antifouling protection (Jensen \& Fenical 1994, Kon-Ya et al. 1995, Bernan et al. 1997), making bioactive substances from marine microorganisms a new research frontier of natural product chemistry. Although marine fungi have been systemically screened for their antibacterial activity (Cuomo et al. 1995, Christophersen et al. 1999), screening for the antibacterial activity against biofilm bacteria (microfoulers) has been scarce. Since microbial fouling is often a prerequisite for the development of a macrofouling community, the control of microbial fouling may help to control macrofouling.

The aims of this study were (1) to screen for the antibacterial activity of marine fungi isolated from Hong Kong waters against 19 fouling bacteria, and (2) to investigate the possible antagonistic interaction between these fungi and bacteria.

\section{MATERIALS AND METHODS}

Isolation of marine fungi from Hong Kong waters. Seawater from the mangrove stand at Kei Ling Ha Lo Wai, Sai Kung $\left(114^{\circ} 21^{\prime} \mathrm{E}, 22^{\circ} 24^{\prime} \mathrm{N}\right)$, was collected in November 2002 using sterile falcon tubes. The samples were diluted 10- and 100-fold with autoclaved filtered $(0.22 \mathrm{~mm})$ seawater (FSW). Aliquots of $200 \mathrm{ml}$ from each water sample were spread onto nutrient agar plates (containing $2 \%$ glucose, $1 \%$ peptone, $2 \%$ agar and FSW). The antibiotics streptomycin and penicillin at final concentrations of 100 and $50 \mathrm{mg} \mathrm{l}^{-1}$, respectively, were added to each agar plate to inhibit the growth of bacteria. Two replicate agar plates were used for each sample. After $2 \mathrm{~d}$ incubation at $27^{\circ} \mathrm{C}$, the inoculated agar plates were examined daily using a dissecting microscope at $20 \times$ magnification for the presence of developing fungal hyphae. Distinct fungal colonies on the agar plates were then transferred to new agar plates for further isolation and purification.
Identification of the fungal isolates. Morphological examination: The pure fungal isolates were maintained on corn meal agar (Oxoid) until sporulation occurred. The spore-producing structures were dissected and removed from the agar surface with a sterile dissecting needle for microscopic examination, and subsequently mounted in glycerol. The microscopic features were then observed using a Leica compound microscope at 40× magnification with bright-field illumination. All isolates were identified to the genus level, based on the morphology of the sporulating structures as well as the morphology and pigmentation of the conidia and conidiophores, following the saccardo classification system (Barnett \& Hunter 1987).

Molecular examination: A molecular approach was adopted to identify non-sporulating strains. These fungal isolates were inoculated into a glucose peptone broth medium (containing $2 \%$ glucose and $1 \%$ peptone) and incubated at $27^{\circ} \mathrm{C}$ on a shaker set at $120 \mathrm{rpm}$ for $1 \mathrm{wk}$. The mycelia were then filtered through 8 layers of sterile cheesecloth and washed with autoclaved double distilled $\mathrm{H}_{2} \mathrm{O}$. DNA extraction was performed using the CTAB extraction method (Zhou et al. 1996). The ITS (internal transcribed space) flanking the 5.8S region of the ribosomal DNA gene was amplified. One pair of primers, ITS5 and ITS4 (White et al. 1990), were used to amplify the ITS1 and ITS2 regions of the rDNA gene cluster. Each PCR mixture contained $1 \mathrm{U}$ of AmpliTaq Gold ${ }^{\text {TM }}$ DNA polymerase (Applied Biosystems), GeneAmp ${ }^{\circledR}$ PCR buffer (Applied Biosystems), $2 \mu \mathrm{M}$ of each primer, $5 \mathrm{mM}$ of each deoxyribonucleotide triphosphate (dATP, dCTP, dGTP and dTTP) (Pharmacia Biotechnology), and $1 \mu \mathrm{l}$ of crude DNA extract in a total volume of $25 \mu \mathrm{l}$. The PCR was performed on a PTC- $100^{\mathrm{TM}}$ programmable thermal controller with a heated lid (MJ Research) under the following conditions: $94^{\circ} \mathrm{C}$ for $4 \mathrm{~min} ; 35$ cycles of $94^{\circ} \mathrm{C}$ for $1 \mathrm{~min} ; 58^{\circ} \mathrm{C}$ for $1 \mathrm{~min}$ and $72^{\circ} \mathrm{C}$ for $1 \mathrm{~min}$; and a final PCR extension at $72^{\circ} \mathrm{C}$ for $7 \mathrm{~min}$. Subsequently, $5 \mu \mathrm{l}$ of each PCR product were subjected to electrophoresis performed in a $1 \%$ agarose gel in TAE buffer $(40 \mathrm{mM}$ Tris-acetate, 1 mM EDTA, $\mathrm{pH}$ 8.0). The PCR products in the gel were visualized with UV illumination after staining with ethidium bromide. The amplified products were then purified with the Wizard PCR preps DNA purification system (Promega) according to the manufacturer's protocol. The purified amplicons were subjected to cycle sequencing using the DYEnamic ${ }^{\mathrm{TM}}$ ET dye terminator cycle sequencing kit (Mega$\mathrm{BACE}^{\mathrm{TM}}$, Amersham Biosciences) and the pair of primers mentioned above. The DNA sequences were bidirectionally resolved using a MegaBACE 500 genetic analyzer (Amersham Biosciences) in sequencing mode. The resultant sequences were compared with the ITS sequences in the GenBank database using 
BLAST (Basic Local Alignment Search Tool) to generate the best match.

Culture of fungal isolates and chemical extraction of fungal broth. The fungal isolates were inoculated and cultured according to the method described above. After incubation, the cultures were homogenized using a biohomogenizer (m133/1281-0) at $8000 \mathrm{rpm}(125 \times g)$ for $2 \mathrm{~min}$. The resultant mixtures were extracted with EtOAc $(2 \times 50 \mathrm{ml})$ and the organic fractions were combined. The solvent was removed using LABOROTA 4002 (HEIDOLPH) at reduced pressure and at $35^{\circ} \mathrm{C}$. The residues were weighed and dissolved in EtOAc to a concentration of $25 \mathrm{mg} \mathrm{ml}^{-1}$ and then subjected to disc diffusion assay.

Disc diffusion assay. A standard disc diffusion assay (Acar 1980) was used to test the antibacterial properties of the fungal extracts (3 replicates per sample). Samples were prepared by loading $250 \mu \mathrm{g}$ fungal extract onto each sterile filter paper disc $(6 \mathrm{~mm}$ in diameter). After the solvent evaporated, the paper disc was placed on the appropriate agar medium, which had already been spread with a suspension of the test bacteria. After incubation for $24 \mathrm{~h}$ at $30^{\circ} \mathrm{C}$, antibacterial activity was evaluated by measuring the radii of the resultant zones of inhibition from the edge of the filter paper discs. In total, 19 bacterial strains that had originally been isolated from natural marine biofilms in Hong Kong waters were tested. They were B1 (Vibrio harveyi), B2 (Rhodovulum sp.), B3 (Pseudoalteromonas sp.), B4 (Vibrio hollisae), B5 (Vibrio sp.), B6 (Shewanella algae), B7 (Vibrio fluvialis), B8 (Micrococcus luteus), B9 (Vibrio furnissii), B10 (Staphylococcus haemolyticus), B11 (Bacillus licheniformis), B12 (Vibrio vulnificus), B13 (Staphylococcus aureus), B14 (Vibrio halioticoli), B15 (Ruegeria sp.), B16 (Pseudoalteromonas piscida), B17 (Moraxella phenylpyruvica), B18 (Vibrio alginolyticus) and B19 (Roseobacter sp.) (Lau et al. 2002, Lee \& Qian 2003). To quantify the general antibacterial activity of fungal isolates, a 'total inhibition zone' was calculated by summing up all the inhibition zones of 1 fungal extract against 19 target bacterial strains.

Antifungal assay. The antifungal activity of the 19 target marine bacteria was also tested against fungal isolates (3 replicates per sample). The fungi tested here were first cultivated on a PDA (potato dextrose agar, Sigma) plate at $27^{\circ} \mathrm{C}$ for $1 \mathrm{wk}$. A small piece of mycelium was then inoculated in the center of a new PDA plate. The fungi were then cultured at $27^{\circ} \mathrm{C}$ and allowed to grow to $2 \mathrm{~cm}$ in diameter ( 3 to $5 \mathrm{~d}$ ). Five $\mu$ l of the culture of the bacterial strain to be tested were then inoculated around the fungal colony ( $1 \mathrm{~cm}$ to the edge of the fungal colony) and kept at $27^{\circ} \mathrm{C}$ for 4 to $7 \mathrm{~d}$ depending on the growth rate of the fungal strain. For the control, $5 \mu \mathrm{l}$ of the sterile culture broth without bacterial inocula were used. The experiment was terminated when the fungal colony grew over the control. The distance between the center and the edge of the fungal colony was measured daily. The inhibition of fungal growth was determined by comparing the radii of the fungal colony under the treatment and control conditions.

Statistical analysis. Data were analyzed using the SPSS statistical package. The differences between the treatments and control samples in the antifungal assay were compared using 1-way analyses of variance (ANOVA) followed by Dunnett's test, and the subgroup comparisons were based on Tukey's tests. In all cases, the threshold for significance was $5 \%$.

\section{RESULTS}

\section{Fungal isolation and identification}

In total, 46 fungal strains were isolated from the seawater samples in this study. These fungal strains were assigned to 17 genera, based on either their morphological characteristics or the ITS sequences (shown in Fig. 1). The dominant genus was Cladosporium, followed by Paraphaeosphaeria.

\section{Antibacterial activity of fungal extracts}

The crude extracts of 32 fungal strains $(70 \%$ of all tested fungal strains) showed antibacterial activity. The inhibition zones of the active extracts against target bacteria in the primary screening tests are listed in Table 1 . The remaining 14 extracts $(30 \%$ of all extracts) did not show any antibacterial activity (not listed in Table 1). The extracts of 9 fungal strains inhibited only 1 target bacterium. A broad spectrum of antibacterial activity was observed for the extracts of F2, F4, F9, F10, F14 and F35, which inhibited the growth of more than 15 target bacterial strains at a concentration of $250 \mu \mathrm{g}$ per disc. In contrast, 4 of the target bacteria (B3, B12, B15 and B19) were very sensitive to fungal extracts (Table 1). Among these bacterial species, the Vibrio vulnificus Strain B12 was particularly sensitive, as it was inhibited by more than $45 \%$ of fungal isolates; B3, B15 and B19 were somewhat sensitive, while B18 was the least sensitive strain, as the growth of this species was inhibited by the extracts of only 4 fungal species.

All Paraphaeosphaeria isolates and $79 \%$ of Cladosporium isolates showed antibacterial activity (Fig. 1). Eight extracts showed strong antibacterial activity with a total inhibition zone of $>20 \mathrm{~mm}$ and the remaining 24 extracts had weak to moderate antibacterial activity with a total inhibition zone of $\leq 20 \mathrm{~mm}$ 


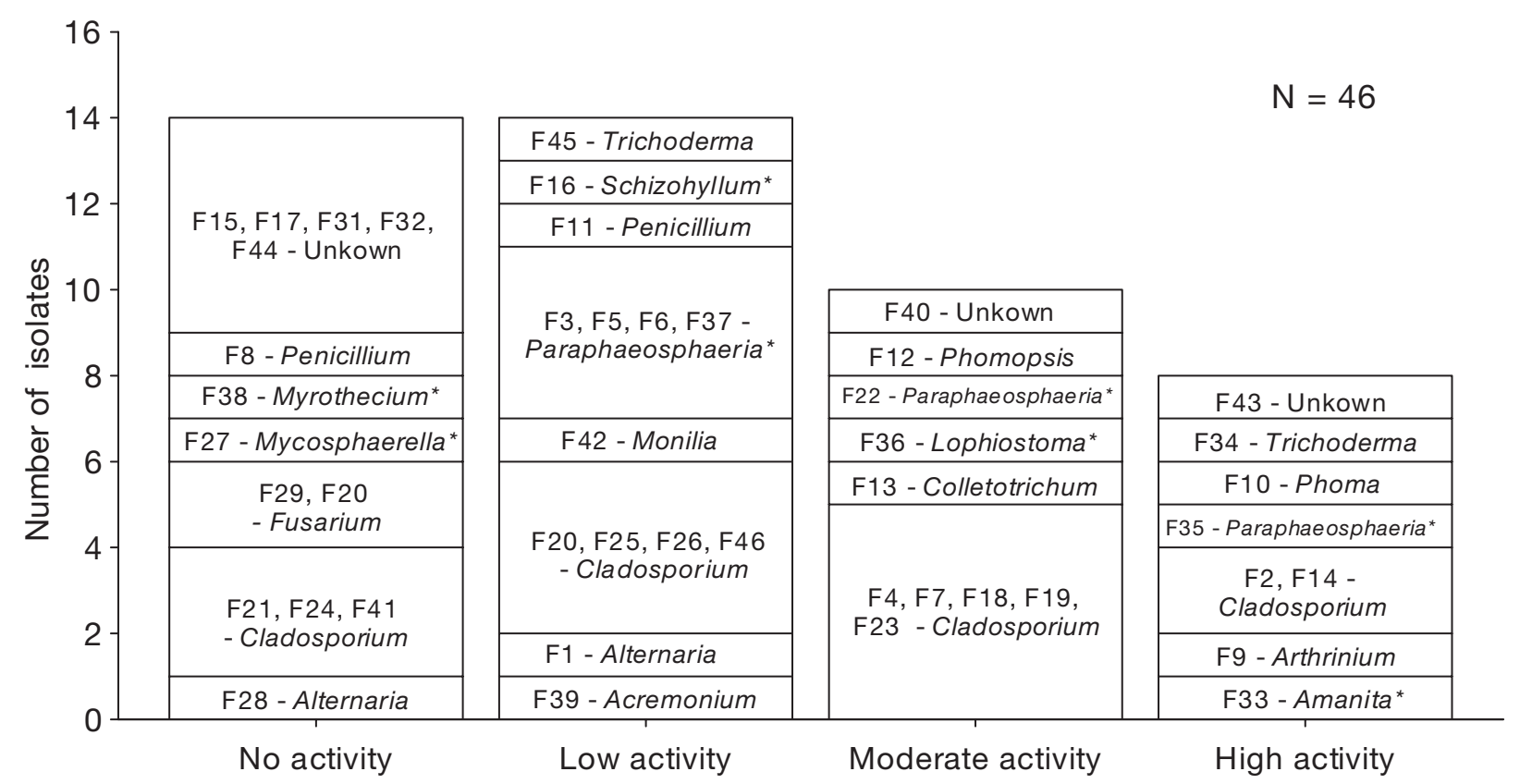

Fig. 1. Generic distribution of the antibacterial activity of fungal isolates. All fungal isolates were identified to the genus level by either morphological examination or a molecular approach. *: isolates identified by the molecular method with the best match from GenBank. Fungal isolates were categorized depending on their antibacterial activity. Low activity: total inhibition zone against 19 target bacteria was $<5 \mathrm{~mm}$; Moderate activity: total inhibition zone was between 5 and $20 \mathrm{~mm}$; High activity: total inhibition zone was $>20 \mathrm{~mm}$

(Fig. 1). The extracts from Strains F2 (Cladosporium), F9 (Arthrinium), F10 (Phoma), F14 (Cladosporium) and F35 (Paraphaeosphaeria) not only had strong antibacterial activity, but also inhibited the growth of more than 15 different target bacteria (Fig. 1, Table 1).

\section{Antifungal activity of the target bacterial strains}

Eight fungal isolates $(17 \%$ of all tested fungal isolates) were sensitive to 11 bacterial strains. Among these 8 sensitive fungal isolates, F3, F5, F6, F22, and F35 all belong to the genus Paraphaeosphaeria (Table 2). F18 (Cladosporium sp.) was the most sensitive fungal strain and its growth was significantly inhibited by $48 \%$ of all target bacterial species. The bacterium Staphylococcus haemolyticus (B10) showed broader antifungal activity. This bacterium significantly inhibited the growth of all the sensitive fungal strains (Table 2).

The growth rates of all the sensitive fungal strains were similar (the radii of the colonies increased about $3.5 \mathrm{~mm} \mathrm{~d}^{-1}$ ), except for 1 fast-growing fungus, F13 (the radii of its colony increased $6 \mathrm{~mm} \mathrm{~d}^{-1}$ ). For F13, the inhibition was obvious only $4 \mathrm{~d}$ after inoculation; for other sensitive fungal strains, the growth of fungi were inhibited by the bacteria from Day 6, and by Day 8 the inhibition had become very distinct (Fig. 2). Therefore, the distances on Day 8 were analyzed statistically, except for the fast-growing strain F13, for which the distance on Day 4 was used.

\section{DISCUSSION}

Although terrestrial fungi have been the major source of the most important antibiotics in human history for decades, marine fungi have only recently become a focal point of interest for natural product chemists. In this study, many waterborne fungal isolates showed promising antibacterial activity against tested biofilm bacteria, while many of these bacterial strains also exhibited various antifungal activities towards certain fungal strains.

Mangrove ecosystems fringe tropical and subtropical coastlines throughout the world and function as nurseries for a wide variety of marine organisms. It is to be expected that these organisms might furnish many new metabolites (Gloer 1997). In this study, 46 filamentous fungi were isolated from seawater taken from a mangrove stand. They were classified into 2 genera of Ascomycetes, 2 genera of Basidiomycetes, and 12 genera of mitosporic fungi. Due to the difficulties in taxonomic identification of some species of mitosporic fungi (e.g. in the genera Cladosporium and Phoma), all the species were identified only to the genus level. 
Table 1. Inhibition zone ( $\mathrm{mm}$ ) of fungal extracts in a disc diffusion assay ( 3 replicates per sample). The 19 target bacterial strains were cultivable bacterial colonizers obtained from the South China Sea. B1, B4, B6, B7, B9, B12, B13, B16, B17, B18 were pathogens and the other 9 bacteria actively induced larval settlement of Hydroides elegans (Lau et al. 2002, Lee \& Qian 2003). Two negative controls were $250 \mu \mathrm{g}$ of the crude organic extract from blank medium (BM) and $10 \mu \mathrm{l}$ of the solvent ethyl acetate (EA). The positive control was $25 \mu \mathrm{g}$ of streptomycin (S)

\begin{tabular}{|c|c|c|c|c|c|c|c|c|c|c|c|c|c|c|c|c|c|c|c|c|}
\hline \multirow{2}{*}{$\begin{array}{l}\text { Fungal } \\
\text { extr. }\end{array}$} & \multicolumn{19}{|c|}{ Target bacteria } & \multirow{2}{*}{ Total $^{\mathrm{a}}$} \\
\hline & B1 & B2 & B3 & B4 & B5 & B6 & B7 & B8 & B9 & B10 & B11 & B12 & B13 & B14 & B15 & B16 & B17 & B18 & B19 & \\
\hline $\mathrm{F} 1$ & - & - & - & 0.33 & - & - & - & - & - & - & - & - & - & - & - & - & - & - & - & 1 \\
\hline $\mathrm{F} 2$ & 1.5 & 1.17 & 3.67 & 3.33 & 1.42 & 3.08 & 0.75 & 0.58 & 2.17 & - & 1.42 & 5.00 & - & 2.83 & 3.17 & 0.25 & 1.33 & 1.17 & 1.33 & 17 \\
\hline F3 & 0.17 & - & 0.42 & - & - & - & - & - & - & - & - & 0.58 & - & 0.25 & 0.17 & - & - & - & - & 5 \\
\hline $\mathrm{F} 4$ & 0.17 & - & 1.17 & 0.5 & - & 0.83 & 0.83 & - & 1.17 & 1.33 & 1.00 & 2.17 & 1.08 & 1.25 & 1.00 & 0.67 & 0.33 & 2.5 & 2.67 & 16 \\
\hline F5 & - & - & - & - & - & - & - & - & - & - & - & - & - & - & - & - & - & - & 2.83 & 1 \\
\hline F6 & - & - & - & - & - & - & - & - & - & - & - & - & - & - & 0.17 & - & - & - & - & 1 \\
\hline F7 & - & - & 1.17 & - & - & 0.17 & 0.83 & - & 0.08 & - & - & 1.00 & - & 0.08 & 4.33 & 0.30 & - & - & 2.33 & 9 \\
\hline F9 & 3.33 & 2.67 & 7.17 & 1.33 & 0.33 & 2.33 & 2.67 & 1.67 & 2.67 & 1.17 & 1.00 & 4.67 & - & 4.33 & 11.83 & 3.00 & 3.50 & 2.17 & 7.17 & 18 \\
\hline F10 & 2.50 & 0.58 & 4.17 & 2.83 & 1.08 & 1.75 & 2.83 & 0.33 & 3.92 & - & - & 7.17 & 4.50 & 2.67 & 1.67 & 2.75 & 0.92 & - & - & 15 \\
\hline F11 & - & - & 0.33 & - & - & - & 0.83 & - & - & 0.25 & - & 1.50 & - & 0.50 & - & - & - & - & - & 5 \\
\hline F12 & - & - & 1.00 & - & - & 0.33 & 0.17 & - & 0.08 & - & - & 0.25 & - & - & 1.17 & - & - & - & 2.83 & 7 \\
\hline F13 & - & - & 0.08 & - & - & - & 0.92 & - & - & - & 0.33 & - & - & - & 2.33 & - & - & - & 3.50 & 5 \\
\hline F14 & 2.67 & 2.67 & 4.17 & 4.17 & 1.00 & 1.42 & 2.67 & 0.67 & 3.83 & 1.50 & 1.00 & 5.33 & 0.50 & 1.67 & 3.67 & 1.08 & 2.17 & - & 2.50 & 18 \\
\hline F16 & 0.33 & - & 0.25 & 0.25 & - & - & - & - & 0.42 & - & - & - & - & - & 0.17 & - & - & - & - & 5 \\
\hline F18 & - & - & - & - & - & - & - & - & 2.00 & 3.33 & 4.50 & 1.00 & - & - & - & - & - & - & - & 4 \\
\hline F19 & 0.17 & - & 0.25 & - & - & 0.50 & - & 0.58 & - & - & 3.00 & 1.08 & - & - & 0.33 & - & - & - & 5.67 & 8 \\
\hline F20 & 0.17 & - & 0.92 & 0.42 & - & - & - & - & - & - & - & 0.42 & - & - & - & 0.08 & - & - & 0.67 & 6 \\
\hline F22 & - & - & 1.17 & - & - & - & - & 4.50 & - & - & - & 0.75 & - & - & 2.50 & - & - & - & - & 4 \\
\hline F23 & 0.17 & - & 0.67 & 0.08 & - & 1.17 & - & - & - & 0.42 & 3.17 & 0.42 & - & - & 0.17 & 0.33 & - & - & 4.83 & 10 \\
\hline F25 & - & - & - & - & - & - & - & - & - & 1.67 & 2.08 & 0.17 & - & - & - & - & - & - & - & 3 \\
\hline F26 & - & - & - & - & - & - & - & - & 1.33 & - & - & - & - & - & - & - & - & - & - & 1 \\
\hline F33 & 1.50 & 1.67 & 1.50 & - & 1.67 & 1.50 & - & - & 0.50 & - & - & 2.33 & 0.67 & - & 4.67 & 2.67 & 1.00 & 0.83 & 5.17 & 13 \\
\hline F34 & 2.33 & - & 1.67 & - & - & - & - & 4.83 & 4.17 & 4.83 & 5.17 & 0.25 & 3.17 & - & 4.67 & - & - & - & - & 9 \\
\hline F35 & 0.08 & 1.67 & 0.50 & 1.83 & 0.33 & 0.08 & - & 0.67 & - & 0.50 & 1.67 & 0.83 & 2.00 & 1.17 & 4.33 & 1.83 & - & - & 2.83 & 15 \\
\hline F36 & - & - & - & 2.00 & - & - & - & 1.33 & - & 1.75 & 1.67 & - & 1.33 & - & - & - & - & - & 0.42 & 6 \\
\hline F37 & - & - & - & - & - & - & - & - & 1.83 & - & - & - & - & - & - & - & - & - & - & 1 \\
\hline F39 & - & - & - & 0.42 & - & - & - & - & - & - & - & - & - & - & - & - & - & - & - & 1 \\
\hline F40 & - & - & - & - & & - & - & - & 1.00 & 0.83 & 3.17 & 0.08 & - & - & - & - & - & - & 2.17 & 5 \\
\hline F42 & - & - & - & - & - & - & - & - & - & - & - & 0.17 & - & - & - & - & - & - & - & 1 \\
\hline F43 & - & - & 1.00 & 2.33 & - & 0.67 & 0.67 & 2.50 & 3.00 & 2.83 & 2.00 & 2.17 & 2.83 & - & 0.67 & 0.50 & - & - & 1.42 & 13 \\
\hline F45 & - & - & - & 0.75 & - & - & - & - & - & - & - & - & - & - & - & - & - & - & - & 1 \\
\hline F46 & 3.17 & - & - & - & - & - & - & - & - & - & - & - & - & - & - & - & - & - & - & 1 \\
\hline $\mathrm{BM}$ & - & - & - & - & - & - & & - & - & - & - & - & - & - & - & - & - & - & - & 0 \\
\hline EA & - & - & - & - & - & - & & - & - & - & - & & - & - & - & - & - & - & - & 0 \\
\hline $\mathrm{S}$ & 2.08 & 2.50 & 2.50 & 1.00 & 2.67 & 3.33 & 1.00 & 3.67 & 2.17 & 2.67 & 1.17 & 2.33 & 1.33 & 3.33 & 5.33 & 3.17 & 4.17 & 2.67 & 3.67 & 19 \\
\hline Total $^{\mathrm{b}}$ & 14 & 6 & 19 & 14 & 6 & 12 & 10 & 10 & 15 & 12 & 14 & 21 & 8 & 9 & 18 & 11 & 6 & 4 & 16 & \\
\hline
\end{tabular}

In this study, the number of strains identified as Ascomycetes was much lower than that of mitosporic fungi, which deviates from previous predictions (Kohlmeyer \& Volkmann-Kohlmeyer 1991). It is highly possible that most of the fungal isolates obtained in this study were not obligate but facultative marine fungi, or even terrestrial fungi that were able to grow under the isolation conditions applied here.

A special bioassay system for screening the antibacterial activity of fungal isolates was established in this study. Nine species of pathogens and 10 species of ecologically relevant bacteria (effectively inducing larval settlement of Hydroides elegans) obtained from natural marine biofilm were used as target bacteria to screen for antibacterial activity in extracts of marine fungi. Compared to the minimum inhibitory concentration (MIC) assay (Torres et al. 2002) and agar diffusion assay (Kubanek et al. 2003), the disc diffusion assay used here has some shortcomings. For example, the size of the inhibition zone might be affected by the ability of active compounds on the paper disc to diffuse through the agar, thus leading to a possible underestimation of antimicrobial activity. Furthermore, small inhibition zones could also be due to the artefacts such as physical effects of the extracts and might not be due to the presence of antibiotics. However, this assay is still a simple, fast and effective method and has been widely used for antibiotic activity screening. About 


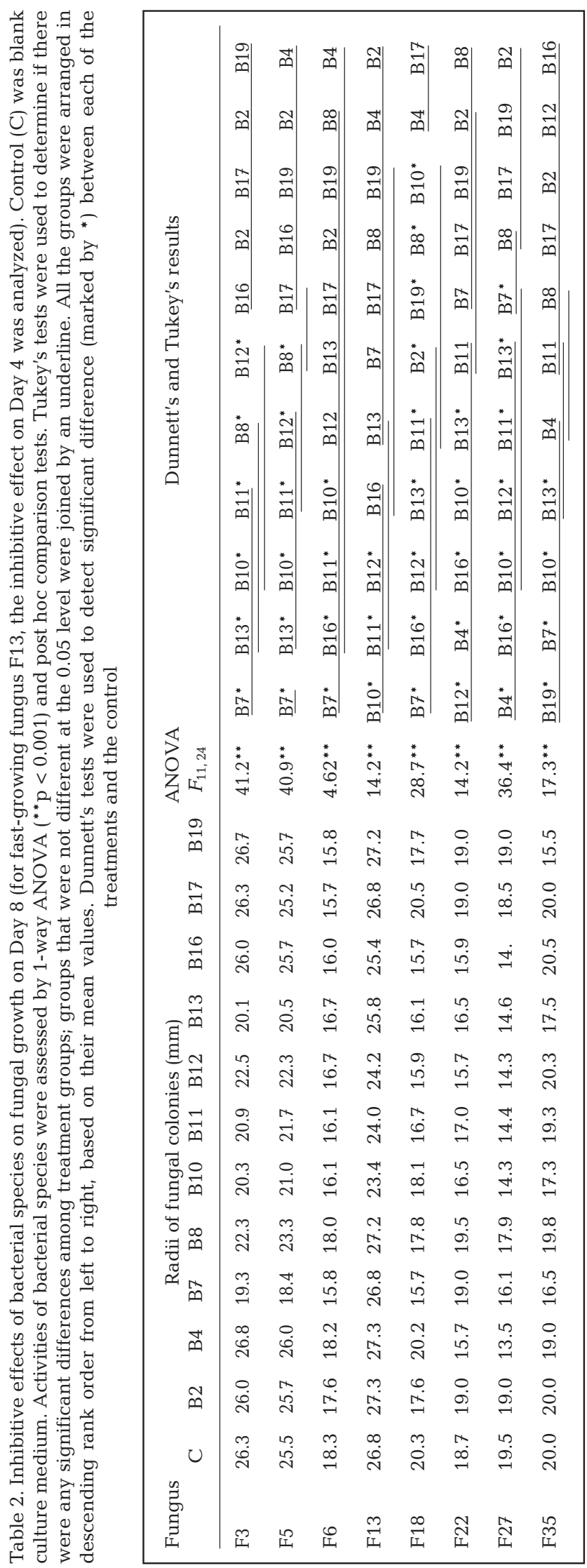

$70 \%$ of the fungal species tested, which belonged to 13 different genera, produced antibacterial compounds. In comparison to other antibacterial activity screening against the standard pathogens Staphylococcus aureus, Escherichia coli, Pseudomonas aeruginosa and Vibrio parahaemolyticus (Cuomo et al. 1995, Christophersen et al. 1999), the percentage reported for marine fungi is much higher. One possible explanation is that fouling bacteria might be more sensitive to fungal extracts than standard pathogens are. However, the higher percentage could also be due to the larger number of target organisms as well as the high concentration of extracts used in this study. The power of bioassay screening is highly dependent on the concentration of the testing extracts and the number of target species used in the bioassay. Studies based on very small number of target species and low testing concentration may lead to biased conclusions and should be avoided in primary screening.

In this study, more than $30 \%$ of the isolates belonged to the genus Cladosporium and the extracts of $79 \%$ of the Cladosporium strains showed antimicrobial activity, which was also very high. Since this genus consists of over 200 species, a large array of secondary metabolites is likely to be produced by this group of fungi. However, there was no correlation between the sensitivity of bacterial isolates to fungal extracts and bacterial phylogenetic grouping. Several target Vibrio strains showed different sensitivity to the same fungal extracts. For example, bacterial Strain B12 (V. vulnificus) was the most sensitive strain and could be inhibited by the extracts of more than $45 \%$ of the fungal species, while another Vibrio strain ( $V$. alginolyticum) was sensitive only to the extracts of 4 fungal species.

Since many fungal isolates did not sporulate in cultures, it was difficult to evenly develop fungal film on agar plates or to prepare a spore suspension and then to observe the spore germination. Therefore, common antifungal assays, such as the MIC assay (Koh et al. 2002) and standard disc diffusion assay (Petitt et al. 1998), were not really suitable for this purpose. Following closely the method described by Holmstroem et al. (2002), a modified assay was established in this study. This method was much easier to manipulate, and contamination could be better avoided. However, the inhibition of fungal growth on agar plates may also be due to the nutrient competition between bacteria and fungi because live bacteria were used in this bioassay. Results of the antifungal assay showed that only 8 fungal isolates ( $17 \%$ of all tested fungi) were significantly inhibited by some target bacterial strains. If nutrient competition affects the result that much, the percentage of sensitive fungal isolates should be much higher. In addition, apart from active bacterial species, when test fungal isolates encounter other bacteria on agar 


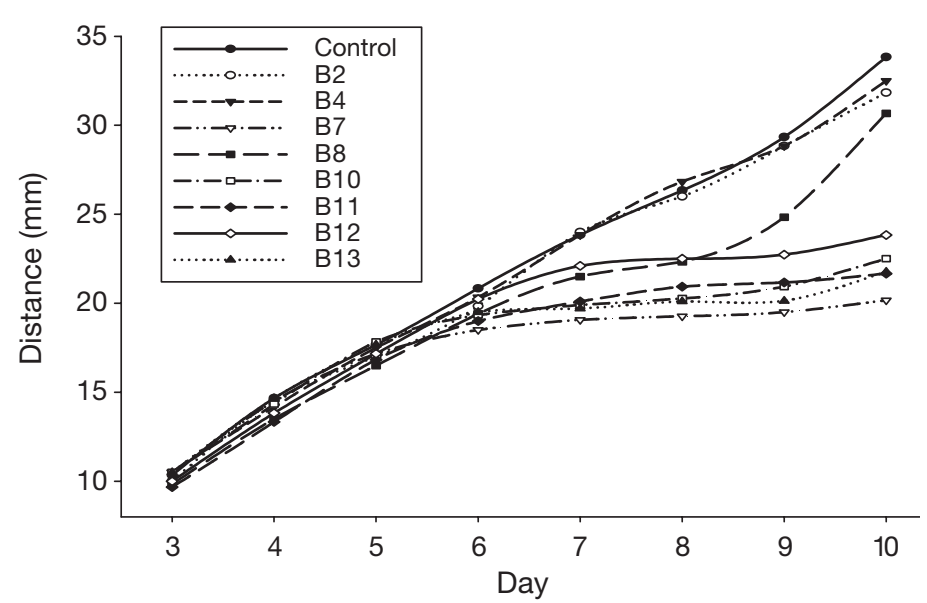

Fig. 2. Antifungal activities of active target bacterial strains against fungal isolate F3 Paraphaeosphaeria sp. Different curves show the growth of F3 under the suppression of target bacterial strains. The control was blank medium

plates, their mycelia just extend over the bacterial colonies without any hindrance. Therefore, the inhibition of fungal growth should be mainly due to the inhibitive effect of active bacterial species rather than the nutrient competition.

Among the 8 sensitive fungal isolates, 5 strains belonged to the same genus Paraphaeosphaeria. Two Staphylococcus bacteria (B10 and B13) showed broad antifungal activity, significantly inhibiting the growth of more than 6 sensitive fungal strains. There seems to be a correlation between the antifungal activity or sensitivity of test microbes and their phylogenetic grouping.

In this study, we found some unexpected results. Certain fungal isolates inhibited the growth of particular target bacterial strains, while these fungal isolates could also be inhibited by the same bacterial strains. For instance, fungal isolates F18, F22 and F35 showed high antibacterial activity against bacterial strains B10 and B11, B8, B13 and B19, respectively, while they were also significantly inhibited by these bacterial strains (Tables $1 \& 2$ ). This result might be due to the different culture method used for fungal growth in the 2 assays: in the disc diffusion assay, we screened antibacterial activity of fungal extracts that were obtained from liquid fungal cultures, while in the antifungal assay tested fungal isolates were cultured on agar plates. Sensitive antibacterial fungi may produce active antibacterial compounds when cultured in a liquid medium; however, the quantity of the active compounds may decrease dramatically when the fungal strains are cultured on agar plates. It was also found that although some bacteria species inhibited the growth of certain fungal isolates, the extracts from liquid culture of most of these active bacteria did not show antifungal activity (data not shown), suggesting that these bacteria may only produce active antifungal compounds when cultured on agar plates. Similar results have been documented with other strains in our laboratory, e.g. a bacterial strain, Pseudoalteromonas peptidysin, produced active metabolites when cultured on an agar plate, but the activity of the bacterial extracts was basically lost when the bacterium was cultured in a liquid medium (Yang et al. unpubl. data).

The fungal strains tested in this study were isolated from seawater in mangrove stands. Recent work in our laboratory showed that most of these fungal strains could also be isolated from natural biofilm, such as many species of Arthrinium, Cladosporium, Paraphaeosphaeria and Phoma (authors' unpubl. data). Therefore, from the results of antimicrobial activity screening, it was found that antagonistic antimicrobial activity widely exists between common fouling bacteria and fungi, suggesting that the competitive interaction between fungi and bacteria during the initial development of biofilms may also affect the chemical signals produced by the film and cannot be neglected when studying the development and function of biofilms.

Based on these results, we concluded that (1) a high percentage of fungal isolates from seawater around mangroves showed antibacterial activity against microfouling bacteria, suggesting that marine fungi can be a source of natural antimicrofouling compounds; and (2) many common fouling bacteria also showed inhibitive effects against certain marine fungi, suggesting a competitive interaction between marine fungi and bacteria during the initial development of natural biofilms.

Acknowledgements. The authors thank Dr. T. K. Goh and Dr. T. F. N. Kwong for their help in fungal identification, and Dr. V. Unkefer for proofreading the manuscript. This study was supported by a Hong Kong Research Grant Council grant (HKUST6100/02M) to P.-Y.Q.

\section{LITERATURE CITED}

Acar JF (1980) The disc susceptibility test. In: Lorian V (ed) Antibiotics in laboratory medicine. Williams \& Wilkins, Baltimore, MD, p 24-54

Barnett HL, Hunter BB (1987) Illustrated genera of imperfect fungi. Macmillan, New York

Bernan VS, Greenstein M, Maiese WM (1997) Marine microorganisms as a source of new natural products. Adv Appl Microbiol 43:57-90

Bettucci L, Alonso R, Rivero S, Diaz V, Martinez S (1999) Coating performance fungal diversity identification in coated aluminium exposed to a marine environment. Proceedings of the 14th International Corrosion Congress (ICC), Cape Town, South Africa, Sep 26 to Oct 1, 1999, Corrosion Institute of Southern Africa, p 133.2

Cheng XC, Varoglu M, Abrell L, Crews P, Lobkovsky E, 
Clardy J (1994) Chloriollins A-C, chlorinated sesquiterpenes produced by fungal cultures separated from a Jaspis marine sponge. J Org Chem 59:6344-6348

Christophersen C, Crescente O, Frisvad JC, Gram L, Nielsen J, Nielsen PH, Rahbæk L (1999) Antibacterial activity of marine-derived fungi. Mycopathologia 143:135-138

Clare A, Rittschof D, Gerhart DJ, Maki JS (1992) Molecular approaches to nontoxic antifouling. Invertebr Reprod Dev 22:67-76

Cuomo V, Palomba I, Perretti A, Guerriero A, D'Ambrosio M, Pietra F (1995) Antimicrobial activities from marine fungi. J Mar Biotechnol 2:199-204

Davey ME, O'Toole GA (2000) Microbial biofilms: from ecology to molecular genetics. Microbiol Mol Biol Rev 64: 847-867

Dube D, Kim K, Alker AP, Harvell CD (2002) Size structure and geographic variation in chemical resistance of sea fan coral Gorgonia ventalina to a fungal pathogen. Mar Ecol Prog Ser 231:139-150

Evans LV, Clarkson N (1993) Antifouling strategies in the marine environment. J Appl Bacteriol Symp Suppl 74: $1195-1245$

Gloer JB (1997) Applications of fungal ecology in the search for new bioactive natural products. In: Wicklow DT, Soderstrom BE (eds) The Mycota. IV. Environmental and microbial relationship. Springer-Verlag, Berlin, p 249-268

Harder T, Lam C, Qian PY (2002) Induction of larval settlement in the polychaete Hydroides elegans by marine biofilms: an investigation of monospecific diatom films as settlement cues. Mar Ecol Prog Ser 229:105-112

Holmstroem C, Egan S, Franks A, McCloy S, Kjelleberg S (2002) Antifouling activities expressed by marine surface associated Pseudoalteromonas species. FEMS Microbiol Ecol 41:47-58

Iken KB, Greer SP, Amsler CD, McClintock JB (2000) A novel biofouling assay using computer-assisted motion analysis of Hincksia irregularis spore swimming. J Phycol Suppl 36:33

Jensen PR, Fenical W (1994) Strategies for the discovery of secondary metabolites from marine bacteria: ecological perspectives. Annu Rev Microbiol 48:559-584

Jensen PR, Jenkins KM, Porter D, Fenical W (1998) Evidence that a new antibiotic flavone glycoside chemically defends the sea grass Thalassia testudinum against zoosporic fungi. Appl Environ Microbiol 64:1490-1496

Kelman D, Kushmaro A, Loya Y, Kashman Y, Benayahu Y (1998) Antimicrobial activity of a Red Sea soft coral, Parerythropodium fulvum fulvum: reproductive and developmental considerations. Mar Ecol Prog Ser 169:87-95

Kelman D, Kashman Y, Rosenberg E, Ilan M, Ifrach I, Loya Y (2001) Antimicrobial activity of the reef sponge Amphimedon viridis from the Red Sea: evidence for selective toxicity. Aquat Microb Ecol 24:9-16

Koh LL, Tan TK, Chou LM, Goh NKC (2002) Antifungal properties of Singapore gorgonians: a preliminary study. J Exp Mar Biol Ecol 273:121-130

Kohlmeyer J, Kohlmeyer E (1979) Marine mycology: the higher fungi. Academic Press, London, p 237-242

Kohlmeyer J, Volkmann-Kohlmeyer B (1991) Illustrated key to the filamentous fungi. Bot Mar 34:1-61

Kon-Ya K, Shimidzu N, Otaki N, Yokoyama A, Adachi K, Miki W (1995) Inhibitory effect of bacterial ubiquinones on the settling of barnacle Balanus amphitrite. Experientia 51: 153-155

Kubanek J, Whalen KE, Engel S, Kelly SR, Henkel TP, Fenical
W, Pawlik JR (2002) Multiple defensive roles for triterpene glycosides from two Caribbean sponges. Oecologia 131: 125-136

Kubanek J, Jensen PR, Keifer PA, Sullards MC, Collins DO, Fenical W (2003) Seaweed resistance to microbial attack: a targeted chemical defense against marine fungi. Proc Natl Acad Sci USA 100:6916-6921

Lam C, Harder T, Qian PY (2003) Induction of larval settlement in the polychaete Hydroides elegans by surfaceassociated settlement cues of marine benthic diatoms. Mar Ecol Prog Ser 263:83-92

Lau SCK, Mak KKW, Chen F, Qian PY (2002) Bioactivity of bacterial strains from marine biofilms in Hong Kong waters for the induction of larval settlement in the marine polychaete Hydroides elegans. Mar Ecol Prog Ser 226: 301-310

Lee OO, Qian PY (2003) Chemical control of bacterial epibiosis and larval settlement of Hydroides elegans in the red sponge Mycale adherens. Biofouling 19(Suppl):171-180

Martin D, Uriz MJ (1993) Chemical bioactivity of Mediterranean benthic organisms against embryos and larvae of marine invertebrates. J Exp Mar Biol Ecol 173:11-27

Michalek K, Bowden BF (1997) A natural algaecide from soft coral Sinularia flexibilis (Coelenterata, Octocorallia, Alcyonacea). J Chem Ecol 23:259-273

Mtolera MSP, Semesi AK (1996) Antimicrobial activity of extracts from six green algae from Tanzania. In: Bjork $M$, Semesi AK, Pedersen M, Bergman B (eds) Current trends in marine botanical research in the East African region. Sida, Marine Science Program, Department for Research Cooperation, SAREC, Stockholm, p 211-217

Petitt KR, Petitt GR, Hazen KC (1998) Specific activities of dolastatin 10 and peptide derivatives against Cryptococcus neofirnabs. Antimicrob Agents Chemother 42:2961-2965

Pietra F (1997) Secondary metabolites from marine microorganisms: bacteria, protozoa, algae and fungi. Achievements and prospects. Nat Prod Rep 14:453-464

Qian PY, Thiyagarajan V, Lau SCK, Cheung SCK (2003) Relationship between bacterial community profile in biofilm and attachment of the acorn barnacle Balanus amphitrite. Aquat Microb Ecol 33:225-237

Rittschof D, Hooper IR, Costlow JD (1986) Barnacle settlement inhibitors from sea pansies, Renilla reniformis. Bull Mar Sci 39:376-382

Strongman DB, Miller JD, Calhoun L, Findlay JA, Whitney NJ (1987) The biochemical basis for interference competition among some lignicolous marine fungi. Bot Mar 30:21-26

Torres YR, Berlinck RGS, Nascimento GGF, Fortier SC, Pessoa C, Moraes MO (2002) Antibacterial activity against resistant bacteria and cytotoxicity of four alkaloid toxins isolated from the marine sponge Arenosclera brasiliensis. Toxicon 40:885-891

Wahl M, Jensen PR, Fenical W (1994) Chemical control of bacterial epibiosis on ascidians. Mar Ecol Prog Ser 110: 45-57

White TJ, Bruns T, Lee S, Taylor J (1990) Amplification and direct sequencing of fungal ribosomal RNA genes for phylogenetics. In: Innis MA, Gelfand DJ, Sninsky JJ, White TJ (eds) PCR protocols: a guide to methods and application. Academic Press, San Diego, CA, p 315-322

Wieczorek SK, Murray AWA, Todd CD (1996) Biofilm cues and larval settlement. Biofouling 10:309-330

Zhou J, Bruns MA, Tiedje JM (1996) DNA recovery from soils of diverse composition. Appl Environ Microbiol 62: $316-322$ 